\title{
A Case of Atransferrinemia and 35 Cases of Hypotransferrinemia as Detected by Radioassay of Total Iron-binding Capacity of the Serum
}

\author{
Hiroshi Saito, M D, Yoshiaki Kato, M D, Takashi Suzuki, M D, \\ and Hajime Kato, M D \\ Department of Radiology, and Department of Internal Medicine, \\ Nagoya University School of Medicine, Nagoya
}

\begin{abstract}
Total iron-binding capacity (TIBC) of the serum was determined in 600 patients by the radioassay method devised by Saito. Fifty-four $\mu \mathrm{g} / \mathrm{dl}$ of TIBC, which is as low as that of previously reported cases of congenital atransferrinemia, was found in a patient with marked hypoproteinemia probably due to protein losing enteropathy as shown by a high plasma RISA disappearance rate of 41 percent per day. The patient was diagnosed as having secondary atransferrinemia on the bases of hematological findings, iron metabolism and other tests. Thirty-five of 600 patients whose serum TIBC levels were determined by radioassay had low TIBC level below $200 \mu \mathrm{g} / \mathrm{dl}$. Twenty-one of the $35(60 \%)$ had blood diseases, $13(37 \%)$ had malignancies and $7(20 \%)$ had diseases of digestive organs. TIBC was markedly increased in iron deficiency anemia, while it was normal or decreased in other diseases. TIBC radioassay is a simple, highly accurate and efficient method of measuring transferrin.
\end{abstract}

Key Words : Transferrin, Serum iron, Unsaturated iron-binding capcity of serum (UIBC), Protein losing enteropathy (PLE), Hypoproteinemia, Plasma RISA clearance, Radioiron utilization, Storage iron deposition, Mechanism of iron absorption, In vitro saturation assay.

Five cases of congenital atransferrinemia have been reported so far. Besides, there are 4 reports on secondary atransferrinemia and suspected atransferrinemia.

To make diagnosis of atransferrinemia, immunoassay of transferrin (Tf) or measurement of both serum iron (SI) and unsaturated iron-binding capacity (UIBC) is essential. One of the authors, Saito, devised the method of $\mathrm{TIBC}$ radioassay ${ }^{10-12}$, and Res-O-mat TIBC kit based on the method

Received for publication March 2, 1977.

Reprint requests to: Hiroshi Saito, Department of Radiology, Nagoya University School of Medicine, 65, Tsurumai-cho, Showa-ku, Na. goya, 466, Japan. is now commercially available. Recently the authors performed determination of serum TIBC on 600 patients using the TIBC kits and found 35 patients with TIBC levels below $200 \mu \mathrm{g} / \mathrm{dl}$, one of them had extremely low serum $\mathrm{Tf}$ level.

\section{MATERIALS AND METHODS}

TIBC and UIBC were measured by using Res-O-mat TIBG and UIBC kits produced by Dai-ichi Radioisotope Laboratory, Ltd., Japan. The amount of $\mathrm{Tf}$ in $\mathrm{mg} / \mathrm{dl}$ was obtained by dividing TIBC value in $\mu \mathrm{g} / \mathrm{dl}$ by 1.3 . At the same time $\mathrm{Tf}$ was determined by using Behringwerke's Immunodiffusion Platten. 
TIBC was determined on 600 different sera which had been sent to the Radioisotope Laboratory of Nagoya University Hospital for the determination of UIBC. Plasmas or sera obtained from healthy students of Nagoya University School of Medicine were used as normal controls.

\section{Case Report}

M.N., 24-year-old Japanese girl, was admitted to Nagoya University Hospital with suspected protein losing enteropathy on September 9, 1974.

Family history was not contributory. Past history was unremarkable except for passing 2 to 3 loose stools daily since she was a pupil of an elementary school.

In July of 1970, she developed edema on upper and lower limbs, general fatigue and fever of about $39^{\circ} \mathrm{C}$ of 4 days' duration. Proteinuria and decreased plasma protein level were also noted. The edema disappeared after diuretic therapy. She was admitted to Kariya Toyota Hospital with a diagnosis of nephrotic syndrome on July 20, 1970 and was discharged in May of 1971, since physical and laboratory findings were normalized. In July of 1973, edema and hypoproteinemia reccurred. She was treated as inpatient at Anjo Kosei Hospital from August 22 to 27 inclusive. In May of 1974, she developed edema which increased steadily thereafter. In July, she was admitted to Anjo Kosei Hospital with generalized edema, cough, pleural effusion, marked hypoproteinemia and elevated ESR. By kidney biopsy performed on July 31, a pathologic diagnosis of membranous glomerulonephritis was made, while urinary protein was negative. Then she was moved to Nagoya University Hospital for further study.

Physical findings at admission: The patient was rather small but normally developed girl. Height was $148 \mathrm{~cm}$ and body weight $44 \mathrm{~kg}$. BT $36^{\circ} 9^{\prime} \mathrm{C}$. Pulse was 88 per minute and was regular. $\mathrm{BP}$ was $108 / 64$ $\mathrm{mmHg}$. Her conjunctiva appeared anemic and striae cutis distensae were noted on abdominal wall. There was a mild edema on legs. Laboratory data were listed in Table 1. Marked hypoproteinemia with hypalbuminemia, increased $\alpha_{2}$-globulin level, hypocalcemia, hyperlipemia and severe hypotransferrinemia were the outstanding features. High $\mathrm{T}_{3} \mathrm{RU}$ and somewhat low thyroxin level were noted, indicating depletion of thyroxin binding protein.

Course in the Hospital: Despite severe hypoproteinemia, edema was successfully treated with $40-80 \mathrm{mg}$ of furosemide daily, but recurred soon after the drug was withdrawn. On september 30 , she had a brief episode of shock followed by marked tachycardia and tachypnea lasting for several days. In December, she developed leg edema, ascites, fever and cough of several days' duration.

Plasma protein level remained low and rarely rose above $4 \mathrm{~g} / \mathrm{dl}$. Striking hypercatabloic hypoproteinemia, as shown by a rapid RISA disappearance (Figure 1), strongly suggested the existence of protein losing enteropathy (PLE), for urinary pro-

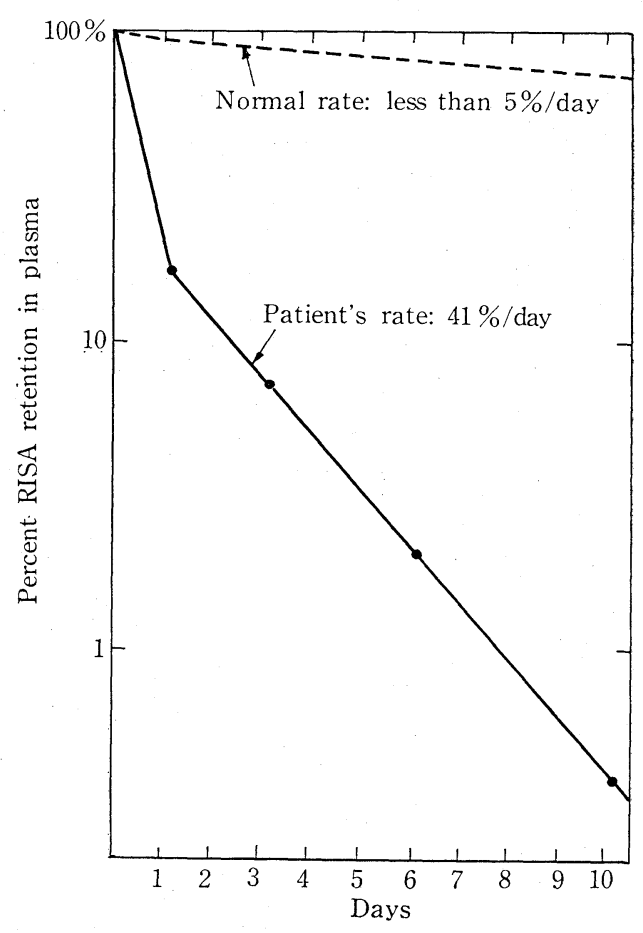

Fig. 1. Plasma RISA disappearance curve. 
Table 1. Laboratory data.

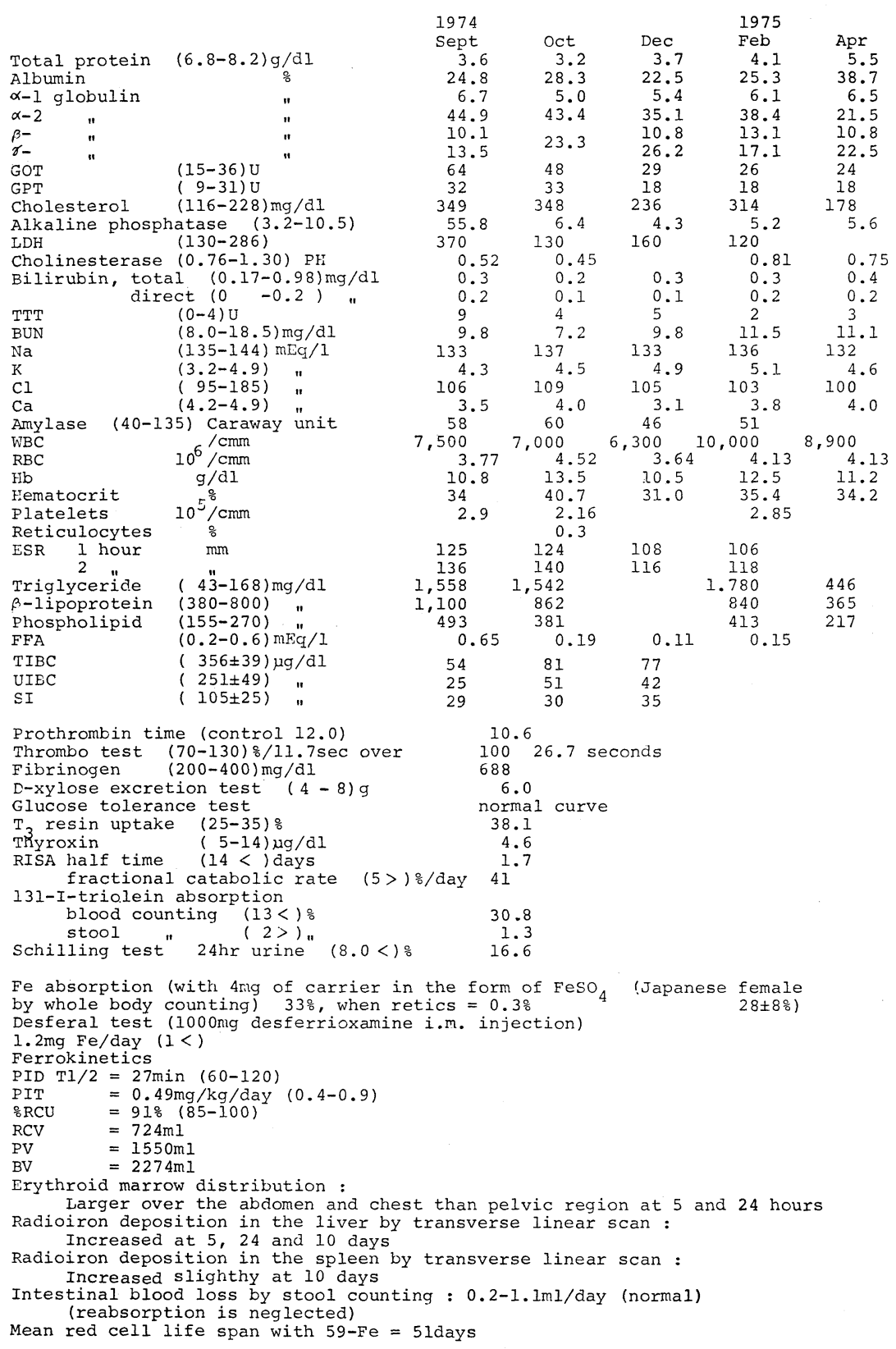

tein was negative on repeated urinalysis. However, UGI, BaE and X-ray examination of the small intestine by means of duodenal intubation revealed no abnormalities in gastrointestinal tract. Jejunal biopsy and absorption studies did not yield any positive results. Although occult blood in stool was often positive, blood loss in the gut determined with radioiron was 0.2 to $1.1 \mathrm{ml}$ per day, i.e., within normal range. $\mathrm{RBC}$ and hemoglobin level were generally within normal limit. Ferrokinetics were performed and the results are shown in Table 1, and Figure 2. 


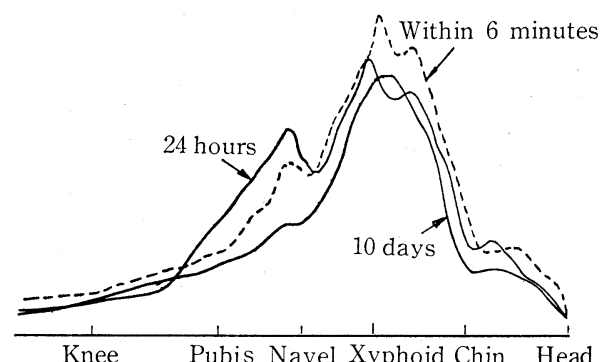

A) Quantitaive body section counting using a ring-type whole-body counter

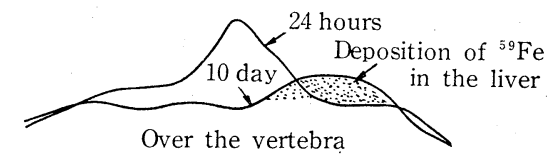

$\frac{\text { Over the spleen, Over the liver }}{\text { Left }}$

B) Transverse linear scan in prone position

Fig. 2. Radioiron distribution along the longitudinal body axis (A) and at the height of liver and spleen (B).

From February 1, 1975 on, she suffered from persistent intractable tachycardia, cough and dyspnea. She died on April 30 in severe dyspnea. Curiously enough, serum protein level rose to $5.5 \mathrm{~g} / \mathrm{dl}$, albumin level to $2.7 \mathrm{~g} / \mathrm{dl}$ and serum cholesterol level decreased to $178 \mathrm{mg} / \mathrm{dl}$ at terminal stage. Permission to perform autopsy was not obtained.

\section{Cases of Low Serum TIBC Level}

Of the 600 patients whose serum TIBC levels were determined during the last one and half years, TIBC was found lower than $200 \mu \mathrm{g} / \mathrm{dl}$ in 35 patients. The underlying diseases are blood diseases such as aplastic anemia, erythroleukemia, chronic myelocytic leukemia, hereditary spherocytosis, hereditary elliptocytosis and paroxysmal nocturnal hemoglobinuria, malignancies such as erythroleukemia, chronic myelocytic leukemia, cancers and Hodgkin's disease, diseases of digestive organs such as liver diseases, and protein losing enteropathy and endocrine diseases such as hyperthyroidism and hyperparathyroidism. The details are listed in Table 2.
Table 2. Thirty five cases having TIBC value lower than $200 \mu \mathrm{g} / \mathrm{dl}$.

\begin{tabular}{|c|c|c|c|c|}
\hline Cases & & TIBC & $\mu g / d l$ & \\
\hline Aplastic anemia & (2) & 172, & 186 & \\
\hline Pure red cell aplasia & (1) & 174 & & \\
\hline Pancytopenia & (1) & 135 & & \\
\hline Hemosiderosis & (3) & 143 & 196,193 & \\
\hline Hered. spherocytosis & (2) & 169, & 181 & \\
\hline " elliptocytosis & (1) & 187 & & \\
\hline $\begin{array}{l}\text { Paroxysmal nocturnal } \\
\text { hemoglobinuria }\end{array}$ & (1) & 192 & & -Blood diseases \\
\hline $\begin{array}{l}\text { Hemolytic anemia } \\
\text { unknown etiology }\end{array}$ & (2) & 159, & 161 & \\
\hline Anemia unidentified & (1) & 186 & - & \\
\hline Hodgkin's disease & (3) & 162, & 181,192 & \\
\hline $\begin{array}{l}\text { Chronic myelocytic } \\
\text { leukemia }\end{array}$ & (1) & 160 & 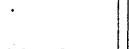 & \\
\hline Erythroleukemia & (3) & 157, & 163,184 & \\
\hline Uterine cancer & (3) & 158, & 174,197 & -Malignancies \\
\hline Iung cancer & (1) & 145 & & \\
\hline Chordoma & (1) & 153 & & \\
\hline Hepatoma & (1) & 121 & & \\
\hline Liver cirrhosis & (1). & 181 & & \\
\hline $\begin{array}{l}\text { Malnutrition + } \\
\text { Diabetes mellitus }\end{array}$ & (1) & 136 & & $\begin{array}{l}\text { Diseases of } \\
\text { digestive organs }\end{array}$ \\
\hline $\begin{array}{l}\text { Protein losing } \\
\text { enteropathy }\end{array}$ & (2) & 146, & 176 & \\
\hline Hypoproteinemia & (2) & 54 & $150-$ & \\
\hline Hyperthyroidism & (1) & 160 & & \\
\hline Hyperparathyroidism & (1) & 193 & & \\
\hline
\end{tabular}

In contrast, marked increase in TIBC was observed only in iron deficiency anemia. TIBC tended to decrease in hemochromatosis and renal failure, as seen in Table 3.

Table 3. TIBC, UIBC and SI as determined by radioassay mathod.

\begin{tabular}{|c|c|c|c|}
\hline Cases & TIBC & $\begin{array}{l}\text { UIBC } \\
\mu \mathrm{g} / \mathrm{d} 1\end{array}$ & $\begin{array}{c}\mathrm{SI} \\
(\mathrm{TIBC}-U I B C)\end{array}$ \\
\hline $\begin{array}{c}\text { Normal male } \\
\text { range }\end{array}$ & $\begin{array}{l}316 \pm 31 \\
258=368\end{array}$ & $\begin{array}{l}207 \pm 44 \\
132 \pm 270\end{array}$ & $\begin{aligned} 109 & \pm 30 \\
55 & -179\end{aligned}$ \\
\hline $\begin{array}{c}\text { Normal female (17) } \\
\text { range }\end{array}$ & $\begin{array}{l}356 \pm 39 \\
296=442\end{array}$ & $\begin{array}{l}251 \pm 49 \\
160=360\end{array}$ & $\begin{aligned} 105 & \pm 25 \\
71 & -162\end{aligned}$ \\
\hline Polycythemia vera & $309 \pm 60$ & $242 \pm 77$ & $67 \pm 38$ \\
\hline Hemochromatosis (15) & $262 \pm 45$ & $62 \pm 55$ & $199 \pm 37$ \\
\hline Aplastic anemia & $284+61$ & $70+56$ & $214+55$ \\
\hline Renal failure (7) & $254 \pm 41$ & $161 \pm 49$ & $93 \pm 39$ \\
\hline Iron deficiency anemia & $418+41$ & $389+41$ & . $31+15$ \\
\hline
\end{tabular}

\section{DISCUSSION}

A case of hypoproteinemia associated with marked Tf deficiency: The TIBC level of the case was as low as that of congenital atransferrinemia reported so far. In previously reported cases, the relation of "TIBC $(\mu \mathrm{g} / \mathrm{dl})=\mathrm{Tf}(\mathrm{mg} / \mathrm{dl}) \times 1.3$ is not seen; Tf values were 3 to $9 \mathrm{mg} / \mathrm{dl}$ and TIBG were 24 to $50 \mu \mathrm{g} / \mathrm{dl}$. Either overestimation of TIBC or inaccuracy of $\mathrm{Tf}$ measurement may account for such a marked discrepancy. TIBC value by radio- 
assay and $\mathrm{Tf}$ value by immunoassy correlated well ${ }^{9,12)}$. Variation of $\mathrm{Tf}$ values measured by using Behringwerke's Partigen Transferrin Immunodiffusion Platten can be significant ${ }^{12)}$, for very small amount of serum is used for immunoassay. The low Tf value as measured by immunoassay might be caused by the alteration of $\mathrm{Tf}$ itself. It should be noted that TIBC radioassay is accurate, highly reproducible and free of possible iron contamination as experienced in colorimetry. Radioassay is an excellent and indispensable method for measuring TIBC and $\mathrm{Tf}$ as confirmed by others $^{13-16)}$.

Rapid disappearance of intravenously administered RISA in this case cannot simply be attributed to increased protein loss in the gut. Two factors should be taken into account, ie., increased degradation and loss of protein. Measurement of plasma disappearance rate of ${ }^{131} \mathrm{I}-\mathrm{Tf}$, detection of lymph in intestinal tract and measurement of ${ }^{131}$ I-PVP in stool were scheduled but not performed. Diagnosis of plasma protein loss in the gut is made by counting ${ }^{131} \mathrm{I}-\mathrm{PVP}$ in stool, however, actual amount of loss of protein cannot be estimated. ${ }^{51} \mathrm{Cr}$-albumin is not superior to ${ }^{131} \mathrm{I}-\mathrm{PVP}$, because the release of ${ }^{51} \mathrm{Cr}$ and resultant short life are prominent. The test for PLE by using ${ }^{67} \mathrm{Cu}$ ceruloplasmin is considered to be most reliable, but it was not available for us. In this case, extremely low plasma protein level was observed in association with a very rapid plasma RISA disappearance rate of $41 \%$ per day, the highest ever experienced here. However, Yoshino et al. ${ }^{17)}$ reported a plasma RISA disappearance rate of $60 \%$ per day in PLE.

The results of absorption studies on vitamin $\mathrm{B}_{12},{ }^{59} \mathrm{Fe}$ and ${ }^{131} \mathrm{I}$-triolein were all normal or above normal in this patient. Her nutritional state had been well maintained until persistent dyspnea developed. Hypoproteinemia due to a failure to synthesize protein, as seen in malabsorption syndrome or liver cirrhosis, can be ruled out from rapid RISA disappearance rate and laboratory data. Although profound hypo- proteinemia, hy poalbuminemia, hyperlipemia and kidney biopsy finding were compatible with nephrotic syndrome, absence of urinary protein will exclude the possibility of kidney disease as a cause of plasma protein depletion. Thus intestinal protein loss is the most likely mechanism of hypoproteinemia in this case, but its etiology remains unknown.

Although short red cell survival was noticed in this case, it is not necessarily assumed that deficient $\mathrm{Tf}$ is somewhat related to hemolysis, for anemia due to iron deficiency or other cause is usually accompanied by a certain degree of hemolysis. Brief febrile episodes occasionally took place during the course. Inflammation may be a cause of hemolysis and sometimes it may cause a decrease of $\mathrm{Tf}^{18}$. However, it seems unlikely that such a significant decrease of $\mathrm{Tf}$ level in this patient is caused by inflammation. Mean red cell life span (RCLS) of the case measured with ${ }^{59} \mathrm{Fe}$ was as short as that in the case reported by Sakata et $\mathrm{al}^{3}$. Although radioiron loss in stool was normal, occult blood in stool was often positive in this case. Furthermore, RCLS obtained by using ${ }^{59} \mathrm{Fe}$ tends to be shorter than that determined by ${ }^{32} \mathrm{P}-\mathrm{DFP}^{19}$. In view of these facts, actual RGLS in this case may be a little longer.

A striking contrast to simple iron deficiency anemia was that the saturation rate (\%Sat) was above the normal range in this case. In general, there is a positive relationship between plasma iron disappearance rate (PID $\mathrm{T} \frac{1}{2}$ ) and level of SI. On the other hand, PID $\mathrm{T} \frac{1}{2}$ was short and SI was also low in this patient as in the case of iron deficiency anemia. In most cases of hemolytic anemia, PID $\mathrm{T} \frac{1}{2}$ is shortened while SI and \%Sat are increased.

Generally speaking, increased body iron stores is one of the factors decreasing \% RCU. All cases of previously reported congenital atransferrinemia ${ }^{1-5)}$ had been transfused with blood, but our case received no blood transfusion. For this reason, perhaps, 
decrease in $\% \mathrm{RCU}$ was not observed in this case despite the decrease of $\mathrm{Tf}$. In cases of congenital atransferrinemia, it is not clear whether the same quantity of iron was deposited as that supplied by transfused blood, or larger quantity of iron than that given by blood transfusion was deposited owing to the developement of hemochromatosis. In this case, ${ }^{59} \mathrm{Fe}$ appeared as a peak of early incorporation in the erythroid marrow within 6 minutes after injection and its distribution pattern 6 to 24 hours thereafter was similar to that of iron deficiency anemia except for the occurrence of a peak over the abdomen as shown in Figure 2A. Radioiron distribution pattern differs from iron deficiency anemia in that some of radioiron deposition was actually observed as shown in Figure 2B. If the patient had received a large amount of blood, the amount of radioiron deposition would have been much larger. Radioiron was deposited in the liver in this case unlike the radioiron turnover as observed in patient with hemochromatosis, or in patient with extramedullary hematopoiesis. In view of radioiron deposition in the liver and hemolysis as indicated by short RCLS, it is not likely that $\% \mathrm{RCU}$ of the patient is $91 \%$. Perhaps \%RGU might have been overestimated. Of the previously reported cases of atransferrinemia, those in whom iron metabolism was thoroughly studied are listed in Table 4. As seen in the Table, iron absorption is enhanced in all cases. The reason why iron absorption is markedly enhanced in spite of increased iron storage and low UIBC is not known. As far as

Table 4. Iron metabolism in congenital and ecquired atransferrinemia.

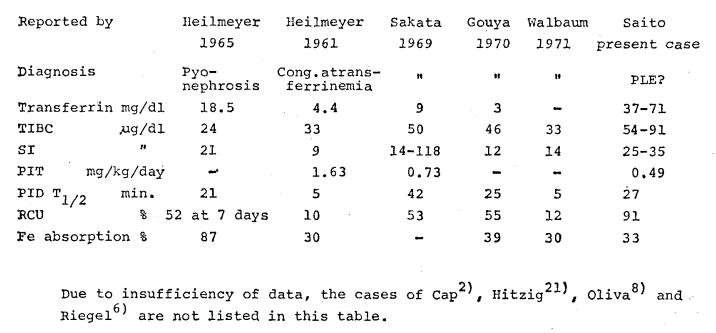

Jap J Med Vol 16, No 4 (Oct 1977) atransferrinemia is concerned, UIBC does not seem to play an important role in iron absorption. As mentioned above, many similarities and some differences were observed between this and previously reported cases of atransferrinemia ${ }^{1-8)}$, and iron deficiency anemia. On the basis of hematological findings, especially of ferrokinetic study mentioned above, this case can be called atransferrinemia.

Cases having TIBC level below $200 \mu \mathrm{g} /$ $\mathrm{dl}$ : It is well known that in normal subjects UIBC level is around $200 \mu \mathrm{g} / \mathrm{dl}$. Therefore, subjects having TIBG level lower than 200 $\mu \mathrm{g} / \mathrm{dl}$ are unusual. We set up a tentative standard and found 35 cases whose TIBC was lower than $200 \mu \mathrm{g} / \mathrm{dl}$. Twenty-one of the 35 cases had blood diseases, 11 of which were of non neoplastic nature. Thirteen cases of the 35 had malignant diseases. Seven cases of the 35 had diseases of digestive organs, including 2 cases of PLE. None of patients with kidney diseases had decreased TIBC level. Majority of patients with hypotransferrinemia had blood diseases in our series. Kozuru ${ }^{9,20)}$ reported that the decrease of TIBC was frequently found in tumors, nephrosis and PLE. Considering the factors influencing Tf level, hypotransferrinemia may frequently be found in diseases of blood, digestive organs and kidneys and in malignant tumors.

If $T I B C$ radioassay is adopted as routine laboratory procedure, atransferrinemia will be more frequently detected.

ACKNOWLEDGEMENTS: We would like to express our cordial thanks to Dr. Mitsuo Kozuru, Third Department of Internal Medicine, Kyushu University School of Medicine for his kindness in sending the literatures on atransferrinemia.

\section{REFERENCES}

1) Heilmeyer L, Keller W, Vivell O, Keiderling W, Betke K, Wöhler F, Schultze HE: Kongenitale Atransferrinämie bei einem sieben Jahre alten Kind. Deutsche med. Wsch, 86: 1745, 1961. 
2) Cap J, Lotska V, Mayerova A: Congenital atransferrinemia in an eleven month old baby. Cesk. Paediat, 23 : 1020, 1968.

3) Sakata $\mathrm{T}$ : A case of congenital atransferrinemia (in Japanese). Shôni Rinshô, 32 : 1523, 1969.

4) Gouya N, Miyazaki S, Odate S, Ushio B : A congenital atransferrinemia and family survey (in Japanese). Nippon Rinshô, 28 : $2110,1970$.

5) Walbaum R: Deficit congenital en transferrine. Lille Medical, 16: 1122, 1971.

6) Riegel C, Thomas D : Absence of beta-globulin fraction in the serum protein of a patient with unexpected anemia. Report of a case. New England J. Med, 255: 434, 1956.

7) Heilmeyer L, Merker H, Wetzel HP, Klemm $\mathrm{O}$, Burmeister P, Haas R: Atransferrinämie bei nephrotischen Syndrom. Deutsche med. Wsch, $90: 1649,1965$.

8) Oliva G, Dominici G, Latini P, Cozzolino G : Sindrome nefrotica atransferrinemica. Minerva Medica, 59: 1297, 1968.

9) Kozuru M, Inoue K: Transferrin and hemopexin (in Japanese). Rinshô Byôri, 22: 632, 1974.

10) Saito $\mathrm{H}$ : Method for determining total ironbinding capacity of serum (TIBC) with radioiron by eliminating iron from transferrin (in Japanese). Acta Heamatol. Japon, $33: 555$, 1970.

11) Saito $\mathrm{H}$ : New method for determining total iron-binding capacity of serum (TIBC) with radioiron by eliminating iron from trans. ferrin. J. Nucl. Med, 12: 489, 1971.

12) Saito H, Iguchi $K$, Odawara $M$, Nakane $K$ : A simple method for determining total ironbinding capacity using radioiron (in Japanese). Radioisotopes, 22: 14, 1973.

13) Kariyone S, Sato M, Fujimori K, Miki M,
Uchida T, Wakizaka G, Nakajima K: A study on the method of determination of total iron-binding capacity of serum using radioiron (in Japanese). Radioisotopes, 22 : 540, 1973.

14) Kashiwamori $T$, Hara $M$, Sato $K$ : Determination of total iron-binding capacity of serum with Res-O-mat Fe. (in Japanese)

15) Akizuki K, Suzuki T, Tanaka T: Clinical studies on the method for determining TIBC using radioiron (in Japanese). Rinshô Ketsueki, 14 : 795, 1973.

16) Okazaki T, Okada H, Kato T, Yanagida M, Miyamura S: Studies on the method for determining total iron-binding capacity of serum with radioiron. Testing of Res-O-mat Fe kit "TIBC" (in Japanese). Rinshô Ketsueki, $15: 1303,1974$.

17) Yoshino K, Kadoma K, Kobayashi N : Protein losing gastroenteropathy (in Japanese). Nippon Rinshô, 28 : 2116, 1970.

18) Cartwright GE, Wintrobe MM: Chemical, clinical, and immunological studies on the products of human plasma fractionation. XXXIX. The anemia of infection. Studies on the iron-binding capacity of serum. J. Clin. Invest, $28: 86,1949$.

19) Saito $\mathrm{H}$, Yamada $\mathrm{H}$ : Studies on red cell production and destruction in various hematological disorders in view of ferrokinetics. Acta Haematol. Japon, 36: 681, 1973.

20) Kozuru $\mathbf{M}$ : Erythrocyte metabolism and plasma protein. The function of transferrin and pathophysiology (in Japanese). Rinshô Ketsueki, 14 : 480, 1973.

21) Hitzig WH, Schmid M, Betke K, Rothschild M : Erythroleukämie mit Hämoglobinopathie und Eisenstoffwechselstörung. Helv. Paediat. acta, 15: 203, 1960. 